\title{
Stage I Testicular Non Seminoma
}

\author{
Alan Horwich \\ Royal Marsden Hospital and Institute of Cancer Research, Sutton, UK
}

A short manuscript from Istanbul in this issue of ONKOLOGIE [1] illustrates that a surveillance policy for men treated by orchidectomy for stage I non seminoma appears to be a safe approach in that healthcare setting and associated with a low treatment burden overall. The report is on a small patient series $(\mathrm{n}=70)$, followed for a relatively short period (median 18 months), so the overall relapse risk is probably underestimated and it is unsurprising that prognostic factors are hard to identify. For example, there have been two recent reports on unselected North American series [2, 3]. In one, 223 patients had been followed for a median of 52 months, the relapse risk was $26 \%$, and in the second, of 371 patients followed for a median of more than 6 years, the relapse risk was $28 \%$. The relapse risk may be slightly lower with improved initial staging (24\% in patients diagnosed after 1993 [3] but disappointingly, sensitivity does not seem to have improved by an FDG PET CT scan [4]. Both of the series reports confirmed the importance of lymphovascular invasion (LVI) in the primary tumour and this was associated with a relapse risk of approximately $50 \%$. A tumour with predominant embryonal carcinoma histology carries similar risk.

Most published series agree that the relapse risk wanes rapidly after the first year of follow up. The two North American series demonstrate $75-85 \%$ of relapses are in the first year and that only $3-4 \%$ occur more than 2 years after orchidectomy. The site of relapse is most commonly in retroperitoneal lymph nodes (77-88\% of relapses in the North American series) and more than $50 \%$ of relapses are detected by a rise in tumour markers in the serum. Relapse confined to the thorax is very uncommon.

As well as its lower reported relapse rate, the Istanbul series is notable for its intensive use of CT scanning in follow up. The carcinogenic risk from a limited number of scans is theoretical and not very high and the dose from a CT scan of the abdomen and pelvis has decreased by a factor of 2-3 since the 1980s [5]. However, the data from most surveillance series suggest no benefit from continuing to scan after 2 years and a Medical Research Council Trial suggested in more than 400 patients (mainly without LVI) no significant clinical disadvantage in basing a follow up schedule on only 2 scans, one at 3 and one at 12 months after orchidectomy [6].

Given the efficacy of treatment of systemic disease, should all patients with stage I non seminoma be managed by surveillance, as has been suggested for stage I seminoma [7]? The treatment burden modeling by Kollmannsberger et al. [2], even in patients with vascular invasion and a $50 \%$ relapse risk, suggested that surveillance overall would be associated with a lower treatment burden, specifically about $25 \%$ fewer chemotherapy cycles compared to a policy of adjuvant chemotherapy in this subgroup using 2 cycles of BEP (bleomycin, etoposide, cisplatin). However, 2 considerations strengthen the case for the alternative approach of adjuvant treatment. One is that not all patients are compliant with attending for follow up, which implies a risk of relapse with advanced disease with worse prognosis. A detailed psychosocial study has noted the difficulty of identifying these patients prospectively [8]. Secondly, there is preliminary evidence from 2 studies that a single cycle of BEP may be almost as effective as 2 cycles in the adjuvant setting. The German Testicular Cancer Study Group performed a randomised trial in 382 patients following orchidectomy [9]; 191 patients had a retroperitoneal lymph node dissection (RPLND) and 191 had 1 cycle of BEP. The 2-year recurrence-free survival was $92 \%$ vs. $99 \%$ respectively. In the surgical arm, most relapses were in the retroperitoneum, suggesting that this challenging surgery should be reserved for specialist centres. The very low relapse risk after a single cycle of BEP raised the idea that this would be more cost-effective than 2 cycles. A subsequent report from the SWENOTECA collaboration gave outcomes in 745 patients with stage I non seminoma treated between 1998 and 2005 [10]. Of 302 patients managed with a single cycle of adjuvant BEP, including 157 with LVI, only 7 (2\%) relapsed.

It remains appropriate therefore to individualise management of stage I non seminoma post orchidectomy, and to discuss relapse risks and toxicities with the patient to arrive at an agreed policy to which both physician and patient can commit.

\section{KARGER \\ Fax +497614520714 \\ Information@Karger.de}

www.karger.com (c) 2011 S. Karger GmbH, Freiburg

0378-584X/11/0344-0162\$38.00/0

Accessible online at:

www.karger.com/onk
Alan Horwich, MD

Royal Marsden Hospital and Institute of Cancer Research

Downs Road, Sutton, Surrey SM2 5PT, UK

Tel. +44 208-661 3274, Fax -643 8809

alan.horwich@icr.ac.uk 


\section{Acknowledgements}

This work was undertaken in The Royal Marsden NHS Foundation Trust who received a proportion of its funding from the NHS Executive; the views expressed in this publication are those of the author and not necessarily those of the NHS Executive. This work was supported by the Institute of Cancer Research, the Bob Champion Cancer Trust and Cancer Research UK Section of Radiotherapy [CUK] grant number C46/A10588. I acknowledge NHS funding to the NIHR Biomedical Research Centre.

\section{Disclosure Statement}

I certify that I have no affiliations with or financial involvement with any organisation or entity with a financial interest in or in financial competition with the subject matter or materials discussed in the manuscript.

\section{References}

1 Keskin S, Ekenel M, Basaran M, Bavbek S: Surveillance results of patients with stage I nonseminomatous germ cell testicular cancer. Onkologie 2011;34:173-176.

2 Kollmannsberger C, Moore C, Chi KN, Murray N, Daneshmand S, Gleave M, Hayes-Lattin B, Nichols CR: Non-risk-adapted surveillance for patients with stage I nonseminomatous testicular germ-cell tumors: diminishing treatment-related morbidity while maintaining efficacy. Ann Oncol 2010;21(6):1296-301

3 Sturgeon JF, Moore MJ, Kakiashvili DM, Duran I, Anson-Cartwright LC, Berthold DR, Warde PR, Gospodarowicz MK, Alison RE, Liu J, Ma C, Pond GR, Jewett MA: Non-risk-adapted surveillance in clinical stage I nonseminomatous germ cell tumors: the Princess Margaret Hospital's experience. Eur Urol 2010;Dec 22: DOI: 10.1016/j.eururo.2010. 12.010 .

$\checkmark 4$ Huddart RA, O'Doherty MJ, Padhani A, Rustin GJ, Mead GM, Joffe JK, Vasey P, Harland SJ, Logue J, Daugaard G, Hain SF, Kirk SJ, MacKewn JE, Stenning SP; NCRI Testis Tumour Clinical Study Group: 18Fluorodeoxyglucose positron emission tomography in the prediction of relapse in patients with high-risk, clinical stage I nonseminomatous germ cell tumors: preliminary report of MRC Trial TE22--the NCRI Testis Tumour Clinical Study Group. J Clin Oncol 2007;25(21):3090-5.
5 Hricak H, Brenner DJ, Adelstein SJ, Frush DP, Hall EJ, Howell RW, McCollough CH, Mettler FA, Pearce MS, Suleiman OH, Thrall JH, Wagner LK: Managing radiation use in medical imaging: a multifaceted challenge. Radiology 2011;258(3): 889-905.

6 Rustin GJ, Mead GM, Stenning SP, Vasey PA, Aass N, Huddart RA, Sokal MP, Joffe JK, Harland SJ, Kirk SJ; National Cancer Research Institute Testis Cancer Clinical Studies Group: Randomized trial of two or five computed tomography scans in the surveillance of patients with stage I nonseminomatous germ cell tumors of the testis: Medical Research Council Trial TE08, ISRCTN56475197-the National Cancer Research Institute Testis Cancer Clinical Studies Group. J Clin Oncol 2007; 25(11):1310-5.

7 Martin J, Chung P, Warde P: Treatment options, prognostic factors and selection of treatment in stage I seminoma. Onkologie 2006;29(12):592-8.

8 Moynihan C, Bliss JM, Davidson J, Burchell L, Horwich A: Evaluation of adjuvant psychological therapy in patients with testicular cancer: randomised controlled trial. BMJ 1998 F;316 (7129):429-35.
9 Albers P, Siener R, Krege S, Schmelz HU, Dieckmann KP, Heidenreich A, Kwasny P, Pechoel M, Lehmann J, Kliesch S, Köhrmann KU, Fimmers R, Weissbach L, Loy V, Wittekind C, Hartmann M; German Testicular Cancer Study Group: Randomized phase III trial comparing retroperitoneal lymph node dissection with one course of bleomycin and etoposide plus cisplatin chemotherapy in the adjuvant treatment of clinical stage I nonseminomatous testicular germ cell tumors: AUO trial AH 01/94 by the German Testicular Cancer Study Group. J Clin Oncol 2008;26(18):2966-72.

10 Tandstad T, Dahl O, Cohn-Cedermark G, Cavallin-Stahl E, Stierner U, Solberg A, Langberg C, Bremnes RM, Laurell A, Wijkstrøm H, Klepp O: Risk-adapted treatment in clinical stage I nonseminomatous germ cell testicular cancer: the SWENOTECA management program. J Clin Oncol 2009;27(13):2122-8. 